\title{
Computational modelling of micro-seizures and focal seizure onset
}

Yujiang Wang ${ }^{1 *}$, Peter N Taylor ${ }^{2}$, Gerold Baier ${ }^{3}$

From Twenty Second Annual Computational Neuroscience Meeting: CNS*2013

Paris, France. 13-18 July 2013

Pathological micro-domains have been proposed to underpin the generation of local pathological activity, as seen in focal seizures in the epileptic cortex [1-3]. Specifically, so-called micro-seizures have been suggested to be markers for these micro-domains [2,3]. Astonishingly, micro-seizures have also been observed in non-epileptic control patients [3]. This suggests that local activity, such as micro-seizures, only become pathological when in a specific arrangement.

We hypothesize that pathological dynamics could be due to an increased density of micro-domains. To test this, we introduce a computational model on the mesoscopic scale

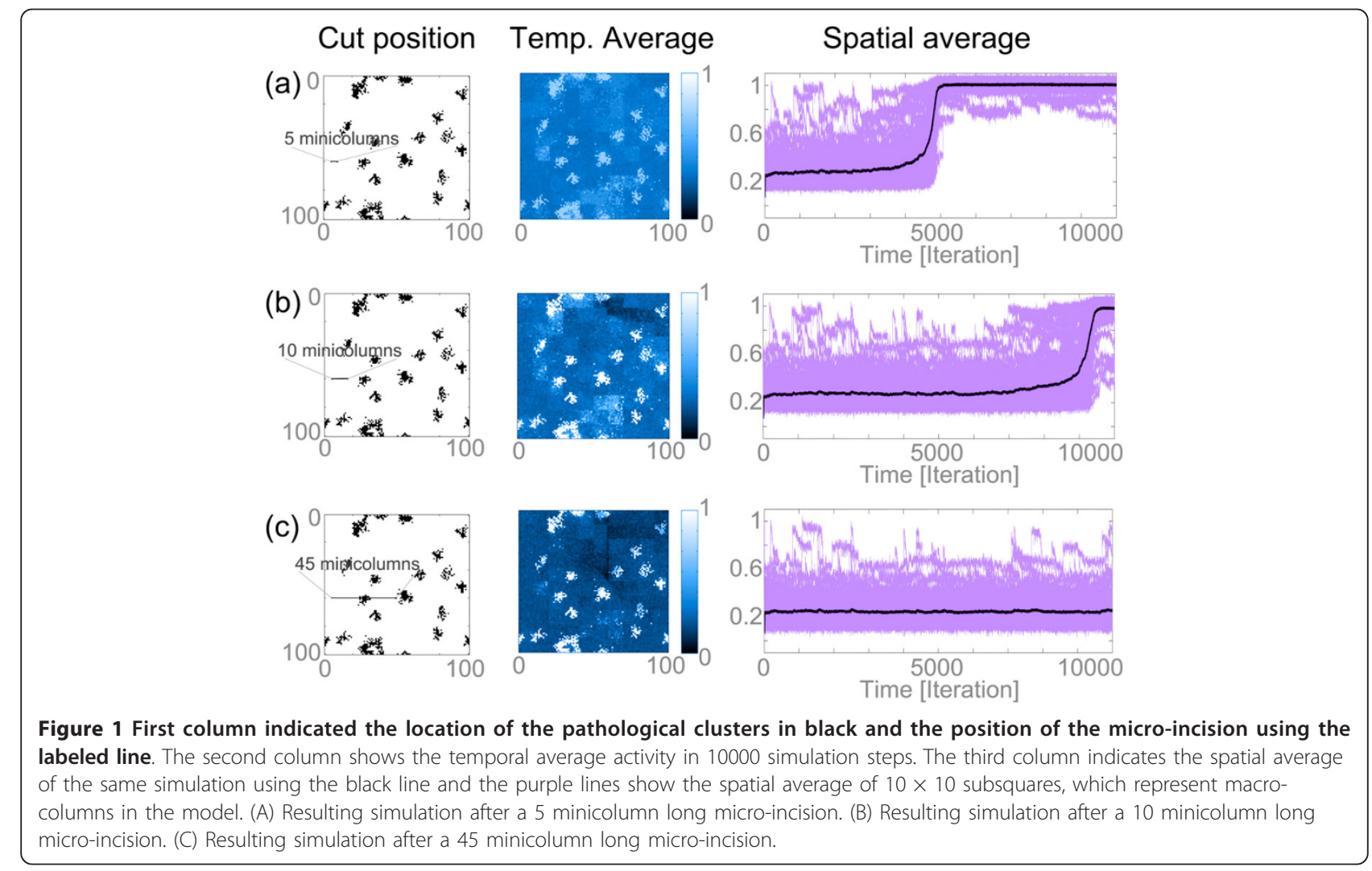

\footnotetext{
* Correspondence: yujiang.wang@manchester.ac.uk

${ }^{1}$ Manchester Interdisciplinary Biocentre, 131 Princess Street, Manchester M1

7DN, UK

Full list of author information is available at the end of the article
} 
of a $5 \times 5 \mathrm{~mm}^{2}$ cortical sheet [4]. The units are modelled as excitable minicolumns. This model also incorporates realistic connectivity schemes observed at this spatial scale [5].

The model shows occasional, non-pathological microseizure occurrences, as well as recruitment of normal tissue into full-blown seizure activity in the presence of dense clusters of hyperactive micro-seizure domains. A specific prediction of this model is that the transition to full-blown seizures can be prevented by using micro-incisions to separate the clusters of abnormally active microdomains (Figure. 1) [6].

\section{Author details}

'Manchester Interdisciplinary Biocentre, 131 Princess Street, Manchester M1 7DN, UK. ${ }^{2}$ School of Electrical \& Electronic Engineering, Nanyang

Technological University, Singapore. 'Division of Bioscience, Faculty of Life Sciences, University College London, London WC1E 6BT, UK.

Published: 8 July 2013

\section{References}

1. Bragin $\mathrm{A}$, Wilson $\mathrm{CL}$, Engel J Jr: Chronic epileptogenesis requires development of a network of pathologically interconnected neuron clusters: a hypothesis. Epilepsia 2000, 41:144-152.

2. Schevon CA, Ng SK, Cappell J, Goodman RR, McKhann G, Waziri A, Branner A, Sosunov A, Schroeder CE, Emerson RG: Microphysiology of Epileptiform Activity in Human Neocortex. J Clin Neurophysiol 2008, 25:321-330.

3. Stead M, Bower M, Brinkmann BH, Lee K, Marsh WR, Meyer FB, Litt B, Van Gompel J, Worrell GA: Microseizures and the spatiotemporal scales of human partial epilepsy. Brain 2010, 133:2789-2797.

4. Wang Y, Goodfellow M, Taylor PN, Gary DJ, Baier G: Computational Modelling of Microseizures and Focal Seizure Onset. In Proceedings of IWSP5. World Scientific;K. Lehnertz, R. Tetzlaff, C. Elger 2013:

5. Voges N, Schüz A, Aertsen A, Rotter S: A modeler's view on the spatial structure of intrinsic horizontal connectivity in the neocortex. Prog Neurobiol 2010, 92:277-292

6. Wang Y, Goodfellow M, Taylor P, Garry D, Baier G: Computational modelling of microseizures and focal seizure onset. International Seizure prediction workshop proceedings, Dresden 2011 (to appear).

doi:10.1186/1471-2202-14-S1-P14

Cite this article as: Wang et al.: Computational modelling of microseizures and focal seizure onset. BMC Neuroscience 2013 14(Suppl 1):P14.

\section{Submit your next manuscript to BioMed Central} and take full advantage of:

- Convenient online submission

- Thorough peer review

- No space constraints or color figure charges

- Immediate publication on acceptance

- Inclusion in PubMed, CAS, Scopus and Google Scholar

- Research which is freely available for redistribution

Submit your manuscript at www.biomedcentral.com/submit 